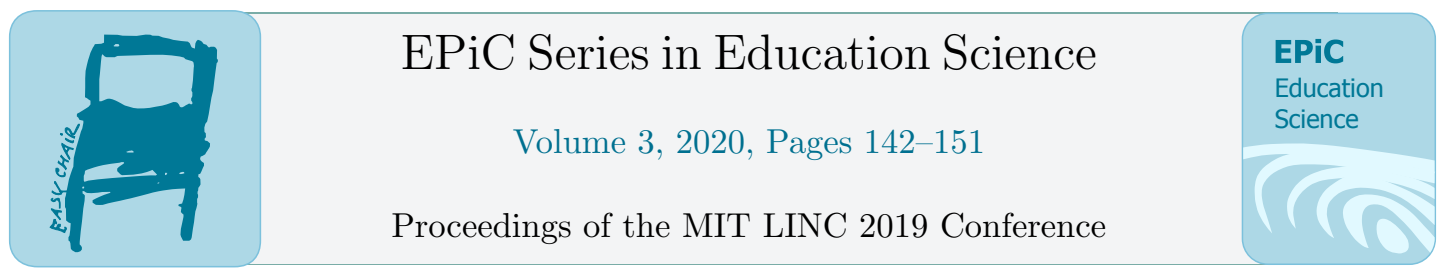

\title{
Bridging Continents - Engagement in the Classroom
}

\author{
Marla Hilderbrand-Chae Greater \\ Lawrence Technical School \\ marla@sparkandover.com
}

\begin{abstract}
STEAM Unit I Challenge - How do we break through limitations created by war?

Although this was the guiding question for our STEAM Innovation Program 2018 first Trimester unit, the real question became "How can you engage learners and compete with the reality of their lives outside of school?" The reference here is not the typical high school experience of competing with social media or the extensive time requirements of intense sports. At Greater Lawrence Technical School, the reality of our students' and families' lives is never simple, but became increasingly difficult after the tragedy of the gas explosions in Lawrence, North Andover, Andover

- 3 of our 4 sending communities. The area most seriously affected was Lawrence, which encompasses $80 \%$ of our student population. Families all throughout Lawrence were removed from their homes, many displaced for months. In this backdrop of personal uncertainty, our program began a transdisciplinary bioreactor project to make medication for Syrians. Students designed their own bioreactors from items that could be found in war-torn Syria (e.g. from bombed hospitals or factories in Damascus). Although Greater Lawrence students continued to struggle with needs for heat and hot water for months, it was this intimate knowledge of hardship that bridged these two worlds - Syria and Lawrence, MA - and the parallel experiences made the learning significant. The success of our Exhibition of Leaning from this unit underscored the importance of engaging students regardless of persisting
\end{abstract}


outside hardship and connecting project-based learning to something within the context of our students lives. The experience that the students themselves lived through during our bioreactor project demanded a rewording of our unit challenge to the following:

- "How do we innovate, adapt, and change to counteract limitations?"

\section{The Background.}

"How do we overcome limitations...created by war?" Most of us in the room almost laughed with excitement and relief as my colleague dashed out the last 3 words that seems to complete our potential transdisciplinary [1] project driving question. "That's it!" I shouted in my head. But even as most of felt resolution with the new addition of these 3 words, this very same colleague who uttered these words said, "I'm actually not sure that works," and we all physically deflated in our chairs.

It was the 5th straight day of curriculum work spent in a hot conference room in the second week of August. We were prepping for year two of the STEAM (Science, Technology, Engineering, Arts and Math) Innovation Program at Greater Lawrence Technical School (GLTS) in Andover, MA. We spent 5 long days in and out of large groups, small groups, sharing state standards, running though team-building exercises and throwing out project and "question" ideas, all the while a full year of unwritten curriculum hanging over our heads. We were ready to feel as if we had made progress. It would actually take two more days to solidify "How do we overcome limitations created by war?" as our guiding question - the theme through which Life Sciences, ELA, History, Math, Engineering, Biotechnology and Music would be exploring and tying in content for the first 12 weeks of the 10th grade class.

If I could point to one of the handful of defining moments in my newly embarked career in education, one work session from the second week of this summer curriculum work stands out. We were watching Most Likely to Succeed [2], a documentary of High Tech High by Greg Whiteley. One scene shows the new 9th grade class entering a Humanities class. The teacher, Mark Aguirre, simply instructed his 9th grade students to assemble the chairs and tables following a white board schematic and then left the room. As I watched the students struggle to understand what was happening and how to rearrange this classroom I felt a jolt of electrifying realization - I am not doing enough. My feelings of pride in surviving through our first start-up year dissolved. We, as a program, are not doing enough. I knew I had to do more. I needed to open more doors for our students through how I run my classroom. I needed to push our approach more - more responsibility for the learning needs to fall on the students; 
projects need to be student-conceived and student run; I needed to push the limits of our teacher team by example.

I heard this phrase once somewhere - "access to the curriculum." Allowing students to "access the curriculum." I believe I heard this term in the context of Special Education Services, but I only know what this means in my own classroom with my STEAM students - this means that I need to do everything in my power to create a classroom experience that will break through whatever that student is going through that very day. How can I break through hurt, despair, anxiety - most often manifested as anger - to open their minds to the amazing world of science, to the elegance of the research that has developed new medications and treatments for diseases, and how groups of people across disciplines and across nations have come together to make a vaccine or to provide medicine and shelter for those in need during after in the aftermath of war? I think of it as my most important function as a "teacher." Each class has to first pull students away from the voice in their heads demanding all their attention and energy. Once that is done the real work can begin.

Having only been a teacher for 5 months, I found myself in the audience of a talk given by Sanjay Sarma at the 2018 Learn Launch Across Boundaries Summit [3] in Boston. I was immediately engaged by both Sarma's lecture style and the research he compiled and presented. Sarma cited research showing that after 10 minutes of focused work, the short-term memory in our brains fills up, and we need to give the brain time to process these short term memories into long term learning. The science rang true with my experience. I had learned quickly in those 5 months that after about 15 minutes into "lecturing" at students I would start to see yawning and heads on tables. These were signals to me that I needed to switch my approach immediately or waste precious class time.

As we finished up our summer work sessions, I kept in mind Most Likely to Succeed and the students I saw in the documentary - discussing their projects during "class" and deciding what to do next, all without direction from a teacher. I knew that our students, with time, could do the same. I also knew what it would take to get them there with all they carried as they walked in the door. How could I instill and sustain motivation throughout the project?

From these various experiences over the preceding months I challenged myself in this project with the following questions:

How can I keep learning to 10-minute segments and then change up the look and feel 
of the classroom to reset the brains of my students?

- How can I successfully allow the students to drive the learning?

- How can I support the social and emotional needs of my students?

- How can I break through these limitations on my students' learning?

\section{The classroom learning approach.}

After several days building empathy with students through interviews with Syrian refugees overseas and videos on the Syrian crisis, the work on the bioreactor project began. For me, projects start with an idea, in this case, "build a bioreactor," and the details are fleshed out as I work backwards to see what the students may need to know to reach this endpoint. I am constantly relying on student feedback - questions I ask them during class and in writing assignments - to decide how to shape their learning experience. Although I have a general project endpoint in mind, I only plan about 1-2 weeks in advance to leave open the possibility of student input into the project direction.

To start, I posed the following questions to the students: What is a bioreactor and what do they make?

What are things in Syria right now that could be used to make a bioreactor?

I like to begin with a class or two of exploration around the specific question being asked - including visual, experiential, and tactile elements. I always like to add in something, often non-traditional with no plans, that they can build. I work in student discussion and questions so I can record data on what they know and what they don't - I learn as much from them (or more) as they learn from the classroom experience.

The format I have developed and like to use is exemplified in the following the following class outline for the Bioreactor Exploration lesson:

3 "stations" were set up at separate tables with the following items:

1. Bioreactor components - What is a bioreactor? Erlenmeyer flasks, tubing, stoppers, bottles

A counter and a hemocytometer

Bacteria and yeast on separate petri dishes

2. Applications/Direct Connections to Bioreactors - What can bioreactors make? Medications 
Syringes

Bottles of medication - some made by bioreactors and some made by chemical synthesis

Some information bioreactor production vs. chemical synthesis

3. Biological Analogies to Bioreactors - How are these things related to a bioreactor?

Items were tactile or exemplified in a series of images Sheep Wool

Bees/honeycomb Silkworms/silk

Of course, the time the students spent at each station was 10 minutes [3]! During this time, there were some written questions to answer at each station, and teachers asked questions through conversing with students as they explored the materials. It was during this time that I was able to gauge the student level of understanding about medications, how they are made and lab bioreactor components.

After the stations, all of the students came together to view a video on what can be made in labs using bioreactors.

The final portion of the class was a build time. There were 4 tables of items that could be found in bombed out hospitals and other buildings in Syria. In groups of 4, students were given 15-20 minutes to see if they could put together portions of a bioreactor from these items. Creating a backdrop to this portion of the class were two photo arrays - one of pristine Western hospitals with gleaming equipment and inviting waiting rooms; and an adjacent walls with image after image of hospitals and factories after bombings, displaying the wreckage and rubble of former buildings in Syria. The message was clear - here was Assad, the leader of Syria, blowing up hospitals and factories that make medication for his own people. Here were images of his people struggling, starving, living in debris, or trying to make the move to refugee camps at the Syrian border. But would the students want to help?

This was the first iteration of what has become a successful work flow model in my classroom and inspired by several sources [2.4]. By successful, I must confess I have a simple but non-scientific measure of student engagement - how many times do students reach for their cell phones and/or ask to go to the bathroom? This curriculum model, and many subsequent versions I have experimented with, generates a low score on this scale and, to me, indicates success. 
It was at this point in the project that the gas explosions in Lawrence forced thousands and thousands of families out of their homes and affected both students and staff at Greater Lawrence Technical School. The initial shock that rocked through the Lawrence community turned into a sustained displacement from homes or in living in homes with no heat or hot water. As the months turned colder, the stress on the students increased visibly. Up until the end of this project (December) some students were still living in homes with no heat or hot water, and one student was living alone with a cousin (both under 18) in a temporary trailer often without heat or hot water (the pipes were freezing as the weather got colder).

\section{The Syria bioreactor challenge.}

Although my teaching team was weeks away from realizing the full impact on our students of the resonating aftershocks from the Lawrence gas explosions, we all continued on with our respective portions of the driving question. History began a comparison of World War I and II and then paired with ELA in a Modern Conflicts segment, Biotechnology centered around yeast bioreactors and antibiotics, and Mechanical Engineering and Electrical Engineering began to work on the design process and the background in electronics needed for building the automated components of a bioreactor. My class continued with how medications affect the body, and how vaccines were made at different time points in recent history. I now felt that students were ready for the more defined challenge that would continue to shape the project:

How can we make a bioreactor to make medicine in Syria?

It was time to go deeper into the Syrian conflict and explored what the bombings meant for the Syrians in terms of lack of medication and access to health care. In another co-taught class with engineering and computer science, we spent time on case studies of individuals in Syria that were affected by lack of medication - a child with cancer with no access to life-saving treatment, a family that continued to live in Syria that had a medical emergency but couldn't travel far enough to the Syrian border to get help, and a video where we watched a Syrian hospital (with patients inside) get bombed. It was at this point that I heard one previously unswayed student blurt out, "Miss, we have to help them!" I then knew we were ready to start building the bioreactors.

In my approach, the challenge offers the motivation for the learning. In other words, in order to meet the challenge, the students would have an opportunity to first think 
about what they needed to learn to make these bioreactors for Syria. This is an exercise I do together with the students - we sometimes start with something as simple as "What words do you not understand in the challenge?" to "What or where is Syria?" I gather information from these questions to assess where the students are in their learning and what needs to be filled in over the project timeline.

In my classroom the curriculum is "live" - meaning the focus can change during a unit, during a week, or even during a class period based upon student questions, gaps in knowledge, and expressed interest. I often have each class period going in different directions based upon where students are at in their learning. This becomes particularly important given our general student makeup at Greater Lawrence Technical School [5]:

- 1,500 students in Grades 9-12 from Lawrence, Methuen, North Andover, and Andover

- $80 \%$ of the student population is from Lawrence

- $80 \%$ of students are Hispanic/Latino

- $40 \%$ First Language Not English

- $20 \%$ Students with Disabilities

- $66 \%$ High Needs and 52\% Economically Disadvantaged

\section{The period of patience.}

There is so much patience required in this style of inquiry design. Patience is needed to hold on the content and hold on the work on the main project until the student questions begin. It is only "inquiry-based learning" if the inquiry is truly coming from the students. If the "inquiry" comes from us as teachers, we can't expect the revolution we want to see to happen in the classroom. We need to have patience as we present information to open doors and pathways to entice student learning. These are what I call the diversions that can draw students away from their own lives and have them fall almost accidentally into learning.

When a student ventures down a path by asking a question, then the true direction of the project can be defined and the project and learning can proceed. This is what sustains the work over weeks and months. The question "But wait, how are we going to get these bioreactors to actually RUN in Syria if there is no electricity?" starts to define one important strand of the inquiry. "Yes," I responded, "That's a great question. How are we going to do that?"

My excruciating period of patience was rewarded when about midway through the project, I went deeper into the Syrian conflict and what medical needs looked like at 
this time. In a co-taught class with engineering, computer science and biotechnology, we more deeply revealed the effects of the war by studying various case studies of the suffering due to lack of medication. We experienced the learning through videos, through short articles/descriptions, and through hands-on work around bioreactors. It was when one student blurted out in class, "Miss, we have to help them!" combined with more and more questions on medications and bioreactors from many other students that I knew we were ready for my most-anticipated part of the project.

\section{Open Build Time.}

It was time to try what I labeled "open build time." Something I remember seeing in the High Tech High documentary Most Likely to Succeed. I was positioned in the lab, the engineering teacher was positioned in the engineering shop, and the computer science teacher was near the Arduino microcontrollers and motor components. We were ready. What would the students do? Would they work on their projects? Procrastinate in the hallways between the labs and subsequently draw criticism from other teachers in other shops? Would they wander off with their cell phones? The answer is a whole combination of those happened at different times.

The answer is that the disruption to traditional classroom-style learning always takes longer to recover from than we think. But the successes were greater than the failures. The urgency generated by the impending Exhibition of Student Learning kept the far majority of students hustling back and forth between the labs as they came upon different needs for putting together their bioreactors. Student groups are splitting duties, one in the Bio lab and one in Engineering working on different pieces of the project. The choices on what they use and how are theirs. The mistakes are theirs. And most importantly, the successes are their own.

\section{Conclusions.}

It has been 6 months since the completion of this project, and the students continue to reap the rewards of their choices and their hard work. Different subsets of students have presented their work at the 2019 Learn Launch conference, the 2019 Junior Science and Humanities Symposium at Boston University, and to Legislators at the Massachusetts State House in Boston as a part of a MassCUE Education initiative in June of 2019. The students arrive at these events with confidence in their knowledge because they made the all the choices in their project and they did all the work.

What the students showed me throughout this project was that even though almost every single one of them was affected by the gas explosions in Lawrence in one way or another, they chose to draw on this as a strength and show empathy for others 
halfway around the world to help them with their struggles.

This project as affirmed for me that curriculum needs to stay live and open to many possible pathways to the desired learning goal, in this case, building a bioreactor. I have enacted this using these guidelines/methods:

- Only plan 1-2 weeks out. This allows room for student voice and choice, as well as adjustments to student levels of learning.

- Each activity and class is an opportunity for me to learn where students are in their learning and what I need to do next class.

- True learning that can be remembered for months requires engagement and choice

- so I let students choose and experiment with anything they come up with. My answer to any question along this vein is always "Yes."

- Have patience - until students start asking questions they are not ready to truly engage. We as educators provide the environment for them to engage and find their own questions.

- Only when students are ready - present the problem/challenge. Allow them to figure out what they don't know, and what they need to know to answer this question in their own way. Then proceed with the project.

As for my own goals - am I seeing qualities in my students that I hoped for at the beginning of this project and this year? Are students providing the direction of the projects based upon their passions? Are they displaying agency in their own learning?

I wish I could say a resounding yes but the truth is somewhere in between - there have been amazing successes and just as many failures. Different students have reached amazing positive progress in many skill sets - confidence, speaking abilities, researching skills, work ethic and experiencing failure. What I do know is that pushing the limits as to student voice and choice in the classroom and conceiving new and innovative ways to captivate students is my perpetual pursuit.

\section{References}

[1] P. Leavey, Essentials of transdisciplinary research: Using problem-centered methodologies, Left Coast Press, Walnut Creek, CA, 2011

[2] G. Whitely, Director, and T. Dintersmith, and T. Wagner, Producers, Most Likely to Succeed, High Tech High, 2015.

[3] S. Sarma, Using Learning Science Today, Learn Launch Across Boundaries Conference, 
Hynes Convention Center, Boston, MA, 2018

[4] J. Larmer, "Gold Standard PBL: Essential Project Design Elements," PBLworks.org (blog), 2015 